\title{
Study of Hand Painted Kalamkari to Design New Motifs
}

\author{
1. Shalini Singh
}

Shalinis455@gmail.com

\begin{abstract}
Hand Painted Kalamakri also known as the Srikalahasti kalamkari is widely used in clothing, home décor and lifestyle products today. The first thought that comes to mind when one refers to Kalamkari clothing is a dupatta, kurta or a saree. It has a certain image in the minds of youngsters. Apart from it being an expensive textile craft, there is also very little variety in terms of clothing in kalamkari available as daily wear in the market. Which is why as Sud and Sibichan said 'the craft is struggling for survival and its patronage amongst the young is dismal.' The objective of this research is to understand the history and evolution of hand painted kalamkari and create new prints. Secondary data was largely collected through books and also from blogs, newspapers, articles and various websites. To understand the functioning of the kalamkari industry research was done. The aim of this research was to come up with a design solution that appealed to younger tastes as well as their pockets. To achieve this a few interventions were made in the design process. Kalamkari, usually a month long process was reduced to two weeks or less. The prints designed were an amalgamation of trends with tradition but tried to keep the essence of the art intact by imparting a message.
\end{abstract}

KEYWORDS : MOTIFS, COMPUTER AIDED DESIGNING, PRINTS, SRIKALAHASTI.

1. Resource Person, Centre of Computer Education, University of Allahabad, India shalinis455@gmail.com. 


\section{INTRODUCTION}

India had always been known as the land that portrayed cultural and traditional vibrancy through its conventional arts and crafts. The 35 states and union territories sprawled across the country have their own distinct cultural and traditional identities and are displayed through various forms of art prevalent there. Every region in India has its own style and pattern of art, which is known as folk art. The folk and tribal arts of India are very ethnic and simple and yet colorful and vibrant enough to speak volumes about the country's rich heritage (Sharma E. 2015). Folk art in India apparently has a great potential in the international market because of its traditional aesthetic sensibility and authenticity. The rural folk paintings of India bear distinctive colorful designs, which are treated with religious and mystical motifs. Folk art expresses cultural identity by conveying shared community values and aesthetics. It encompasses a range of utilitarian and decorative media, including cloth, wood, paper, clay, metal and other items which are quite popular among foreign tourists because of their ethnic and traditional beauty. Some of the most famous folk paintings of India are the Madhubani paintings of Bihar, Patachitra paintings from the state of Odisha, Phad Paintings of Rajasthan, Kalamkari of Andhra Pradesh, Pichhvai Paintings of Rajasthan, Warli Paintings of Maharashtra, Nirmal paintings of Andhra Pradesh, Aipan of Uttarakhand, Pithoro paintings of Gujarat, Gond and Mandana Paintings of Madhya Pradesh, Kalighat paintings of Calcutta and many more forms (Sharma B. 2013).

Indian art lives from about the 3rd millennium BCE to the modern times. A strong sense of design is art, from then till now. People, in India are not aware of most of the art forms as they are too vast. Though these art traditions are a lot in number, many of them are in an extinct stage and few don't exist. Each form has its own aesthetics and elegance. There are very few people who have the concern towards the art forms, and they come up with great plans amongst which quite a few are breathtaking. Fashion, as mentioned earlier has played a major role in not only bringing the art to limelight but also has ultimately made the art live (Sekar S. 2014).

The research was exploratory and the findings were mainly qualitative in nature. To understand the present kalamkari market I visited a number of stores and spoke to store managers, salesmen and customers. This gave me an idea of the kind of products in the market and their target consumers. Lastly other prints in the market were studied to get an idea of the current trends. 
The market study helped in finalizing a theme for the prints according to the trends. Samples of these prints were created. A catalogue illustrating the application of the prints on casual clothing for youngsters was created.

India is marked by its rich traditional heritage of Folk Arts and Culture. Since the days of remote past, the diversified art and cultural forms generated by the tribal and rural people of India, have continued to evince their creative magnificence. The folk paintings have rich heritage. Folk paintings give aesthetical feelings and remind us about the native life through their colorful line drawings (Dallapiccola A.L. 2011). Further commercialization of these tribal paintings creates a new source of non-agricultural income as these have achieved eminence in the national and international art market. Due to the growing demands of the crafts internationally, different organizations encourage the artists to produce their traditional paintings on handmade paper for commercial sale. Office of Development Commissioner (Handicrafts) Ministry of Textile, Government of India and other agencies are also working and supporting the genuine craft artists directly by arranging various exhibitions, skill oriented trainings, organizing and inviting artists to market events and providing incentives and awards to artists for their work (Sharma E. 2015).

Kalamkari means painting with a pen. It is an exquisite form of textile art with a heritage dating back to the ancient times. The origin of the term can be traced to the early period of alliance between the Persian and Indian trade merchants which identified all painted textile art from India as Kalamkari. 'Kalam' is the Persian word for pen, and 'kari' in Urdu implies the craftsmanship involved. Hence, 'Kalamkari' denotes the myriad manifestations of hand painted textiles with natural dyes. The pen referred to in the term is a short piece of bamboo or datepalm stick, shaped and pointed at its end to form a nib. Created without the use of chemicals or machine Kalamkari art is entirely a handicraft using natural or vegetable dyes and metallic salts called mordents to fix the dye into the cotton fibers. An exact resist process, complex and careful dyeing, sketching and painting of the design and, occasionally, even the addition of gold or silver tinsel into it are the other integral components of this art (Chandra S. 2015).

Hand painted Kalamkari is an ancient textile printing art that finds its roots in the state of Andhra Pradesh. Kalamkari or Qalamkari is a type of hand-painted or block-printed cotton textile, produced in parts of India. The word is derived from the Persian words kalam (pen) and kari (craftmanship), meaning drawing with a pen. The craft made at Machilipatnam in Andhra Pradesh, evolved with patronage of the Mughals and the Golconda sultanat. Kalamkari is the art of drawing and painting with a bamboo pen using natural dyes. 
There are two distinctive styles of kalamkari art in India - one, the 'Srikalahasti' style and the other, the Machalipatnam style of art. The block printed that is practiced in the town of Machilipatnam and the hand painted style that is largely practiced in the town of Srikalahasti. The Srikalahasti style of Kalamkari, wherein the 'kalam' or pen is used for free hand drawing of the subject, and filling in the colours is entirely hand worked. This style flowered around temples and their patronage, and so had an almost religious identity - scrolls, temple hangings, chariot banners and the like depicted deities and scenes taken from great epics Ramayana. Mahabarata, Puranas and mythological classics. Only natural dyes are used in Kalamkari, and it involves seventeen painstaking steps (Bharatuntolstory 2014).

The themes of Kalamkari fabrics are traditionally chosen from the Puranas or epics. These stories are depicted in the form of a series of horizontal panels with the narrative script running through with more important incidents receiving a larger layout. The distinctive temple wall hangings, chariot decorations and canopies of Srikalahasti typically feature Hindu stories, and the images are often identified with text in Telugu, the regional language. Temples were a major inspiration in the Srikalahasti Kalamkari paintings. The art flourished under the patronage of the temples with their demands for hangings with strong figurative and narrative components. This specialisation in figurative work continues till today.

The art of Kalamkari flourished in temple towns along the eastern coast of Andhra Pradesh. With the decline of temples and patronage from royal families the art declined as well. It was in the temple town of Kalahasti near Tirupathi that, during the 1950s, Kamaladevi Chattopadhyaya discovered the dying art of Kalamkari with the help of Jonnalagadda Laxamaiah and Kalappa. There were only two artists left who knew the Kalamkari tradition. But there was no one to pass it down to. With the help of Avani Kalappa, Chattopadhyaya started a training school in the village. The present generation of artists and students has recovered the tradition of Kalamkari and are infusing the art with individual styles (Satpathy V. B.). The discovery of a resist-dyed piece of cloth on a silver vase at the ancient site of Harappa confirms that the tradition of Kalamkari is very old (Kotcherlakota L. N. 2011). Even the ancient Buddhist Chaitya Viharas were decorated with Kalamkari cloth. In the 17th century, Kalamkari paintings were exported to Iran, Burma, the Persian Gulf, Maldives and Malacca. The craft gained immense popularity in the $18^{\text {th }}$ century throughout Europe, with the fabric being used as draperies and bedspreads. The Kalamkari floral and vegetable designs were in great demand, in particular the motif known as the 'Tree of Life'. These fabrics were made into dresses, skirts and jackets and were also used as large wall hangings. 
Today, there are several groups of Kalamkari artisans in Kalahasti. The Srikalahasti Kalamkari Kala Karula Sangham, is one of the co-operatives of Kalamkari artisans, which has worked with the non-government organization Dastkar Andhra and the Crafts Council of India to bring Kalahasti Kalamkari to the forefront (Satpathy V. B.). The former has been instrumental in changing the monochrome red in the wall hangings to a more diverse color palette. New themes such as stories from the Panchatantra were also introduced in addition to the conventional religious depictions.

Textile designs layered the new ideas with those of ancestors. Spirits of the natural world were adapted to accommodate both their original meaning and the new Hindu symbolism. In Indonesia, the bird was connected to heaven and was seen as a conveyer of divine messages. With the arrival of Hinduism this bird was transformed into Garuda, the deity of the sun and a symbol of the ruler, but also retained its former symbolism (Wilkins W. J. 1900).

There were large imports of printed textiles from India into Thailand between (circa, 1850 to 1950) these were popularly called as Saudagiri. They were made of cotton and printed with chintz-like patterns. They were manufactured in the village of Pethapur near Gandhinagar, Gujarat. These had apart from geometric motifs, figurative designs, and seemed to have been inspired from the kalamkari of south India. These were extremely popular among the royalty of Thailand as well. However, in 1950, the import of these textiles was banned in Thailand and there is little evidence of the large share that these textiles had in the Thai market (Das S. 1992).

Kalamkari is an ancient textile craft of India. It is traditionally hand painted or block printed on cotton fabric with vegetable dyes. The painted style grew around the Hindu temples and depicted images of deities and scenes from the Ramayana and Mahabharata (mythological epics). The practice of hand painted kalamkari is currently concentrated in a village called Sri Kalahasti in the state of Andhra Pradesh, India. The printed style flowered under the patronage of the Mughals. The widely seen motifs are those inspired from nature of interlaced leaves, flowers etc. This style is mostly practiced in and around Machilipatnam in todays times (Chisti R. \& Jain R. 2000).

The textile tradition in India is said to be more than 3000 years old. The Indian silks and brocades have been famous among the rich around the world but the simple kalamkari on cotton made a wide impact and revolutionized the textile trade in India in the 18th and 19th century (Purohit P. 2015).

'As early as 1670s complaints had started to be heard from English weavers about the influx 
of cotton from India, by 1696 dyers and linen drapers had joined the protest. 5000 English weavers mobbed the House of Commons in a mass protest against Indian imported goods. Finally in 1701 a law was passed forbidding the import of Indian dyed or printed cottons and silks into Britain, except for re-export' (Das S. 1992).

This was the beginning of the downfall of Kalamkari. There are many other reasons why kalamkari declined so drastically among all other fabric crafts of India. One of the early reasons was the establishment of the European cotton Industry in the eighteenth century. Workers were thrown into punery and master craftsmen died without heir to their trade secrets. Also the rises of the batik industry in Indonesia in the 19th century lead to India's loss of market for the cloth (Chisti \& Jain 2000).

Dr. Bhatnagar Opines 'So clothed in ritual and superstition was this craft that for many years it was restricted to only a handful of practitioners and the technique was a closely guarded secret. Unfortunately many a traditional craftsman has taken this jealously guarded secret with him to his grave and no written records are available of the techniques employed and the colour yielding plants used by him in his work. This has been mainly responsible for the decline of this beautiful art form and we have now barely a dozen dye recipes in the place of over a hundred which existed before' (Crill R. 2008).

One could attribute the downfall of Kalamkari to its long and tedious process which in today's times also turns out to be expensive as natural dyes are not easily available anymore. While the dyeing process takes around a month the preparation to start dyeing is even longer. Each dye has to be prepared from various materials. For instance the black is 'made by soaking hoop iron bits in a solution of jiggery (Molasses) and water in a mud pot. The solution takes about twenty days to mature when it is decanted'. Similar is the case with the other dyes as well. Bhatnagar also mentions 'The influx of cheap chemical dyes drove the final nail in the coffin and Kalamkari craftsmen these days are only too eager to reach out to the readily available artificial dyes for quick and easy production of temple cloth' (Gillow and Barnard 1991).

The adaptability of the artisans as well as the art has become very evident with the above samples of Kalamkari from the 17th and 18th century. While there is a lot of material on the history of the kalamkari fabric and its evolution, the academic literature on the kalamkari market and its current products is very scarce. 'While the evolution and dispersal of dyepainted trade goods are well recorded, there is less evidence of a parallel development in the tradition of narrative hangings for courts and temples in south India. The only surviving links 
appear to be the nineteenth century temple cloths of Palakollu, Madura and Srikalahasti' (Crill R. 2008).

'The Kalamkari temple cloths had strong symbolism and bold colours which did not appeal to the tastes of the Europeans. Compared to the delicate chints paintings these were considered rough and crude. The famous community of temple cloth painters however was still active, and the kalamkari illustrating scenes from Ramayana was shown at the Indian \& colonial Exhibition in London in 1886 . Of the 19th century community of temple cloth painters, in 1915 Hadaway noted with grave concern that only man was still working' (Gillow and Barnard 1991). The period from 1924 up to Independence and beyond saw the near disappearance of the industry at Musalipatnam. At the same time at Kalahasti temple patronage declined and the local land lords lost wealth and power of patronage. In 1952 Kalamkari was revived at Masulipatnam at the instigation of some local textile lovers and with the help of the All India Handicrafts board. The kalamkari as used and made in Iran was taken as model. In 1958 All India Handicraft board set up a training course and school for kalamkari workers, drawing on skills of few remaining kalamkari workers.

While there is a lot of material on the history of the kalamkari fabric and its evolution, the academic literature on the kalamkari market and its current products is very scarce. The textile industry in India is one of the core sources of income for the economy. Rangarajan says 'Textile industry is one of the main pillars holding the Indian Economy. It constitutes about 14 percent of industrial production, 20 percent of total export earnings, 4 percent of GDP and direct employment to an estimated 35 million people. In spite of these, India's entire share in the world textiles trade is still maintained at around 3 percent. Mills, power-looms and handlooms constitute three independent sectors of the Indian Textiles Industry' (Bhatnagar P.2011).

The Handicraft Industry provides employment to innumerable people across rural and urban India, not only to artisans but also designers, activists etc. But the drawback is that the industry is quite unorganized since it is cottage based and decentralized. According to Hashmi 'The Handicraft sector has, however, suffered due to its being unorganized, with the additional constraints of lack of education, low capital, and poor exposure to new technologies, absence of market intelligence, and a poor institutional framework' (Sethna N. 1979).

Hence it should be a job of the design professionals to identify the problems and try and invent and create methods that would boost the industry. Anand in her article in The Hindu about 
Vivek Karunakarns innovation in Kalamkari commences by saying 'Kalamkari comes with certain stereotypical images. Perhaps as a sari or dupatta. Or maybe as a salwar-kurta set or the intrepid have made blouses out of them. It is a fabric that has met with little innovation and the stereotypes haven't helped' (Rangarajan K. 2004).

Fashion in India is probably the most commonly taken path to employ crafts in order to increase their popularity. Sud and Sibichan in their paper say 'There has of late been a shift to a more inclusive partnership between design and artisan community and clearer focus towards pushing the boundaries in fashion by exploring form, surface and material going beyond pure aesthetics' (Hashmi S. K. 2012).

Many professionals have tried to incorporate kalamkari in fashion in order to increase its popularity amongs the young, but in vain. Vivek Karunakarn is one such designer who has tried to give Kalamkari a western look to make it more appealing to the youngsters in his collection for the Kochi International Fashion Week called 'Tres chic' which is an amalgamation of kalamkari and grunge. He has incorporated kalamkari in western garments but not played around much with the prints. Vivek in an interview with Anand says 'We have attempted to give the fabric an international never before done look. Tunics must be the closest the fabric has come to looking different' (Nair And Anand).

Any kind of change and innovation is always better than no change at all. So all efforts made to promote any craft are always appreciated. But the efforts are not always fruitful, like in the case of kalamkari. While Sud and Sibichan talk about the numerous efforts being made to incorporate kalamkari as ceiling art and other innovative manners they also point out that 'the craft is struggling for survival and its patronage amongst the young is dismal.'

The fashion industry is growing more than ever before in India. With the culture of fast fashion coming in rapidly it is necessary to tap into this opportunity where consumers are more than willing to spend on anything that they like. The size of fashion industry in India is worth INR 1542.5 Billion state according to India Retail Report, 2010, as summarised by Sud and Sibichan. They go on to discuss how the 'sheer scale of the industry makes it important enough for the Government to not ignore its importance. The scale of stakeholders and women in particular, involved in this industry from a cotton grower to a consumer is wide. Its impact on the economy therefore cannot be ignored. Its growing economic strength, rising household income, expanding middle class of consumers with high aspirations and increased discretionary spending power, large segment of population belonging to the age group of less than thirty has created visible shifts in the way fashion is perceived and consumed.' 
While craft is being viewed as fashionable, it also needs to be made affordable. While there is more liquidity in cash flow among the youngsters these days, it would be beneficial for kalamkari to adapt and bring about some contemporary changes in its appearance. It could be a turning point for the fabric in the industry and could change the lives of so many artisans involved in the craft.

It is really important to identify the buying market and promote the craft accordingly. If the spending consumer is of a young age group it would be clever to mould a craft to suit their taste. If one aims to promote the craft not just in the domestic market but also international then the changes brought about can be such that suit both. It is our role as a designer to keep track of market trends and bring about changes that will accelerate the growth. As Ghouse explains 'An important aspect of successful handicraft marketing is the positioning of the products in the marketplace.' In a survey conducted by Ghouse the results showed that ' 85 percent cited market awareness and the poor infrastructure as the major export related problems which are a few of the major reasons for India's low export share in the international handicraft market. Poor infrastructure includes frequent power failures, high cost of power, inferior Inland Container Depot (ICD) and rail transportation facilities, poor quality of roads, improper port facilities, etc as compared to other competing nations which makes the buyer interest shift from India to other exporting countries who are better developed infrastructural than India.' But the Indian handicraft industry is such that requires low capital investment. It is easier to bring about a change as cheap labour is available. 'The handicraft sector is highly creative sector and produces large variety of crafts products. This industry is localized segment of the domestic and international market. In India the production of craft products are done on both large and small scale. Because of low capital investment people can start their business on small scale. Through this flexibility the demand and supply can be managed. Though Indian handicraft industry is considered a cottage industry, but it has evolved as one of the major revenue generator over the years. There has been consistent growth of $15 \%$ over few years and the industry has evolved as one of the major contributor for export and foreign revenue generation' (Sud S. \& Sibichan K. M. 2011). 'Kalamkari designs pertaining to different periods in history presented a pictorial record of the changing face of the society through the ages' (Ghouse S. M. 2012). In this project I propose to reflect the current society in the pictorial images on kalamkari to give it a new age look. 


\section{METHODOLOGY}

The research conducted was of exploratory and experimental nature. The research was done to study the state of hand painted kalamkari in the market. Though there is ample literature available on the history and evolution of kalamkari, there is very little information available on the current situation. Thus the exploratory method was chosen to find out the details and bring about a change in the designs.

Data have been collected from internet sources, articles, newspapers, news websites, individual websites and reviews from social networking sites such as facebook and twitter. The nature of data collected was unstructured and qualitative. The information found was not certain since such a research on kalamkari was not conducted earlier.

Traditional Hand Painted Kalamkari was always done on hand woven cotton. But today it is being adapted on a variety of materials such as georgette, crepe, chiffon, silk etc. Even a variety of cottons such as chanderi or kota can be used. Kalamkari is being combined with other crafts such as embroidery work, badla work, zardosi work and so on. The latest trend of 'net' sarees is also seen in combination with kalamkari. Kalamkari is being mainly practiced in Sri Kalahasti with scattered practices in Tamil Nadu. There are more than 250 families practicing the art of Hand Painted kalamkari. And this number is ever growing as NGOs like Dwarka and control costs. Kalam creation artisan Association are constantly making efforts to increase the awareness for the art by organizing training programmes for people below poverty levels. Most of the production happens in large production units with 4-5 people working on one piece as opposed to the traditional method of every piece being a piece of self expression for the individual artisan. There are only 3-4 families that individually practice Kalamkari in the state of Andhra Pradesh.

The motifs seen today are mostly related to nature, birds animals and leaves interlacing through the width of the fabric. 'Tree of Life' and peacocks are most common. The most recent trend is that of wearing mythological figures on dupattas and sarees. Earlier it was considered disrespectful to make mythological figures on clothing. The colours used today are much brighter which indicates they may not necessarily be natural. This change is seen mostly in the mass produced kalamkaris and not those made by individual artisans. Due to its pricing and marketing kalamkari comes across as a fabric only the rich can afford. Most available cater to an older age knowledge from some elders in the family or peers. It is required that the youth is specifically targeted in order to gain their attention. 
The first stage was to conduct a market study of the way kalamkari has been used in various products. This was done by visiting stores that are known to sell traditional as well as contemporary kalamkari products. The products in these stores were reviewed and price points were noted. Unstructured interviews were conducted of the employees of the store asking them questions related to target customers, foot fall, fast selling products etc.

A study of print trends in the market was also conducted. Again various stores were visited to understand the kind of prints available in women's casual clothing.

After studying the various aspects like the process, market with respect to kalamkari and market with respect to other print trends a theme was finalized.

Next stage was to develop sample prototypes. This involved creating designs and implementing them on the fabric.

The final stage is the preparation of a thesis. Initially a rough draft was prepared and submitted to the mentor for her perusal. The conclusions and analysis were supported with relevant data and proof. Then the final document will be submitted that would act as a resource for kalamkari contemporisation.

The market study of prints was done by visiting stores famous for casual youth clothing. Multibrand stores like Shopper's Stop, Lifestyle, Westside and Max that widely catered to the youth were visited to understand the present print trends. After the analysis of prints available it was observed that quirky nature prints were in style. Among the nature prints, birds seemed to be the predominant graphics. This study helped in finalizing the theme for the designs to be created. Most stores stock block printed kalamkari and very little hand painted Kalamkari. It is only now that specific shops in Hyderabad are specializing in hand painted kalamkari products. It is no surprise that the younger generation that is not interested and informed in arts and crafts is pretty clueless about its existence.

The exploratory market research proved that Kalamkari prints are being utilized contemporarily yet not many products are targeted to the youth. Kalamkari being a lengthy procedure and thus expensive seems unsuitable for younger pockets. Keeping current print trends for youth in mind a theme was finalized and experimentations and explorations in kalamkari were done so as to innovate control costs.

Design explorations were made with birds placed against various manmade structures seen in day to day life. This made for quirky prints yet gave out a message of birds being endangered in the city, keeping the story telling aspects of kalamkari alive. 


\section{FINAL DESIGNS}

Sample prints were generated through Reach Fashion Design software so that only required areas would be painted for final products to reduce wastage as well as to make the process faster.

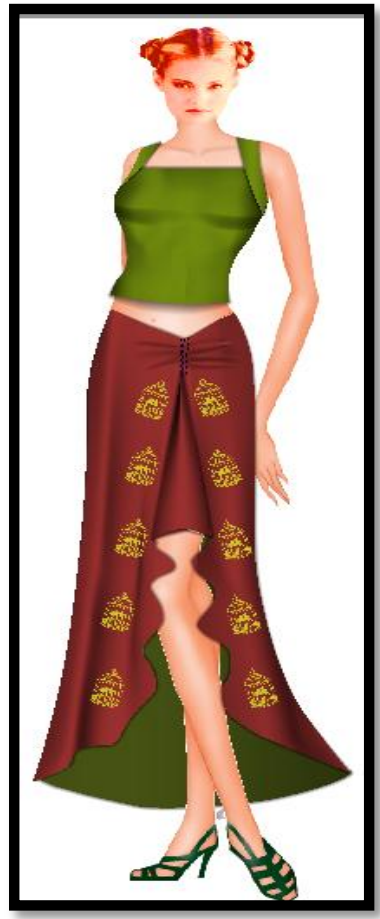

Sample 1

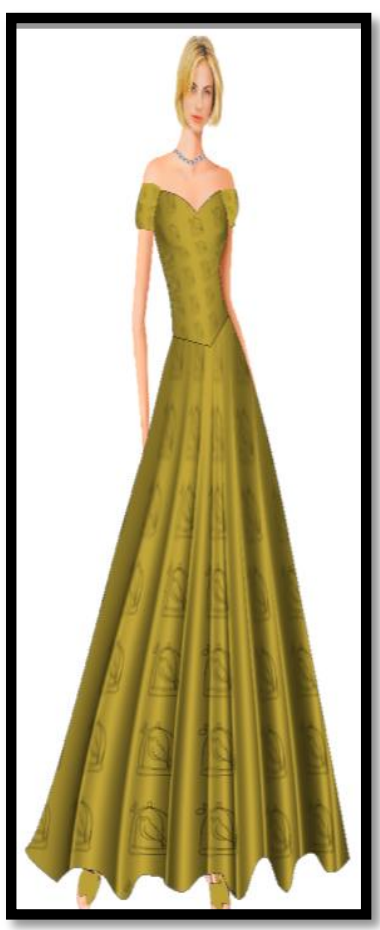

Sample 5

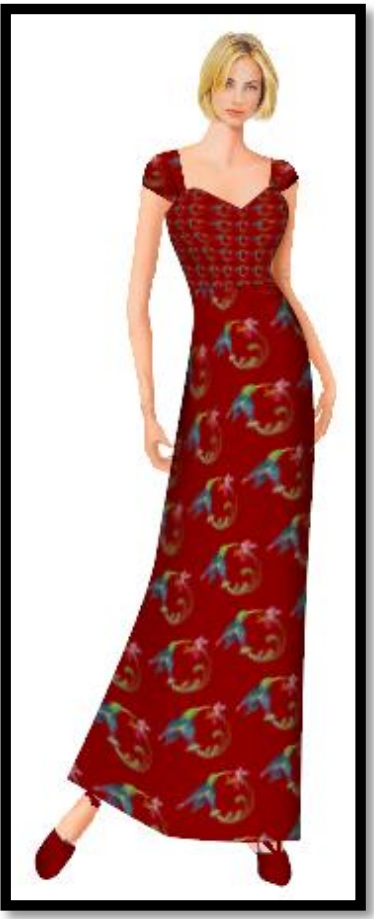

Sample 2

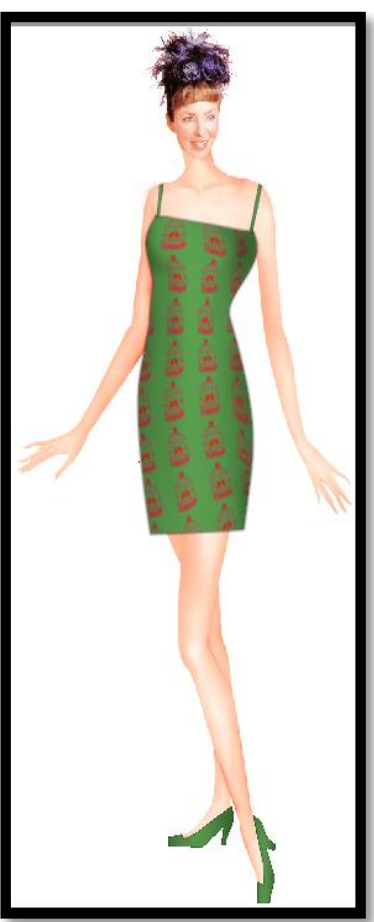

Sample 6

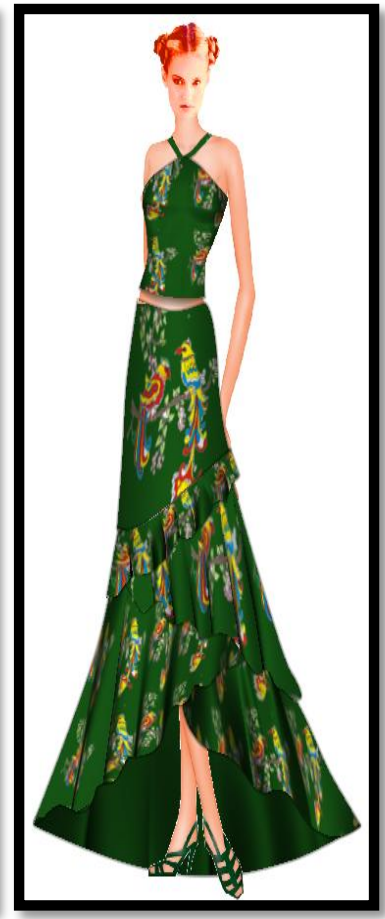

Sample 3

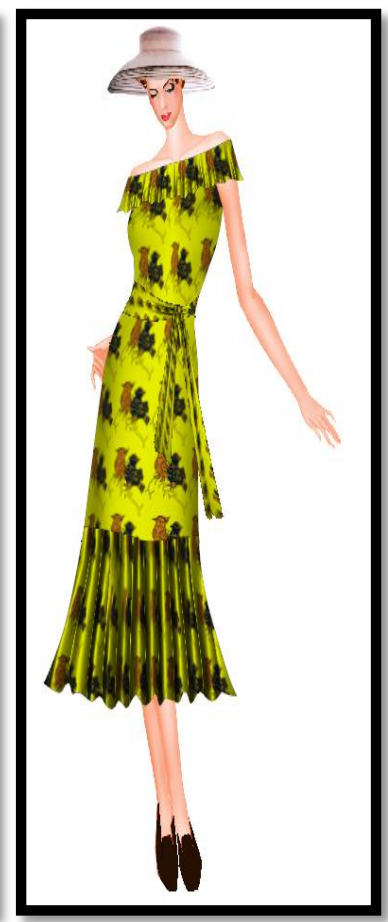

Sample 7

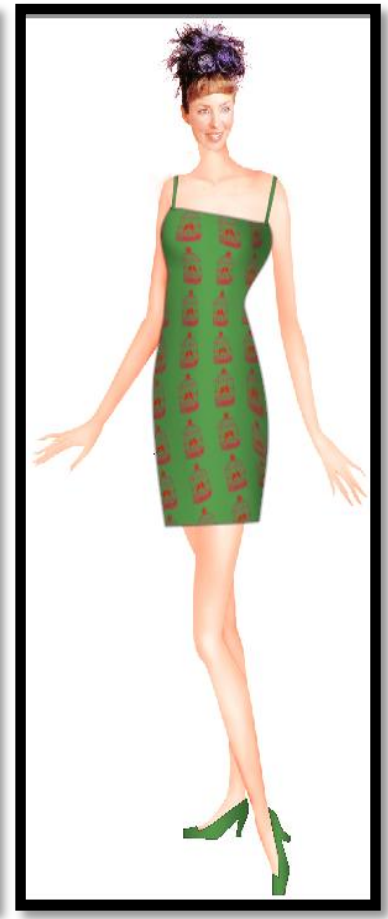

Sample 4

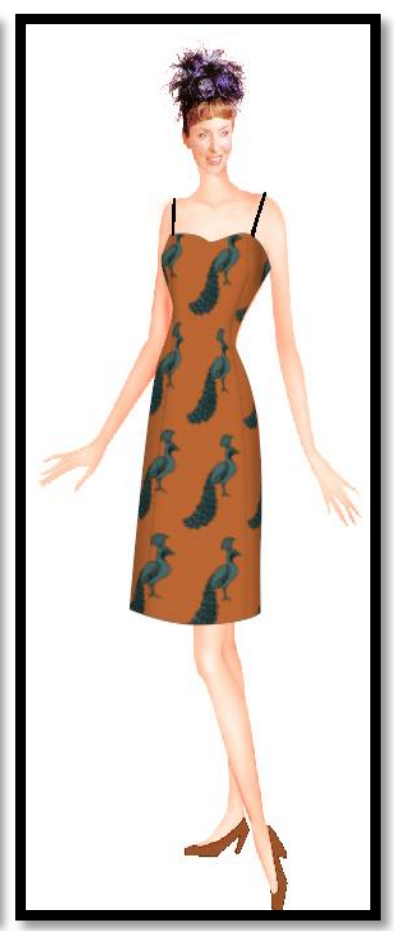

Sample 8 


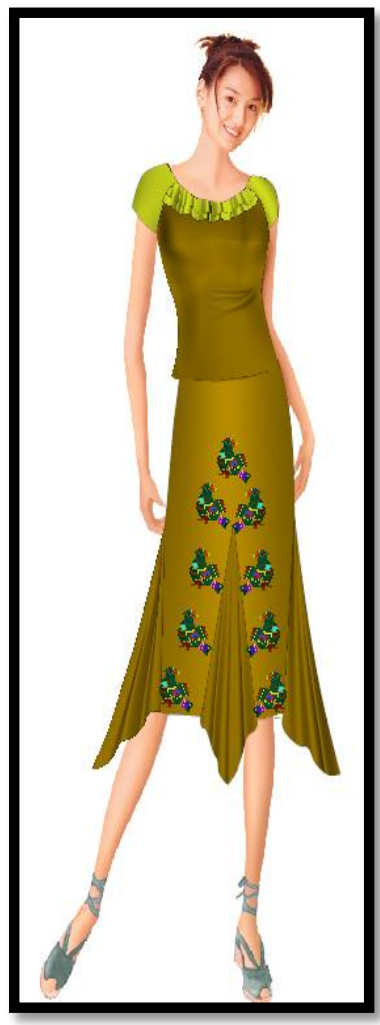

Sample 9

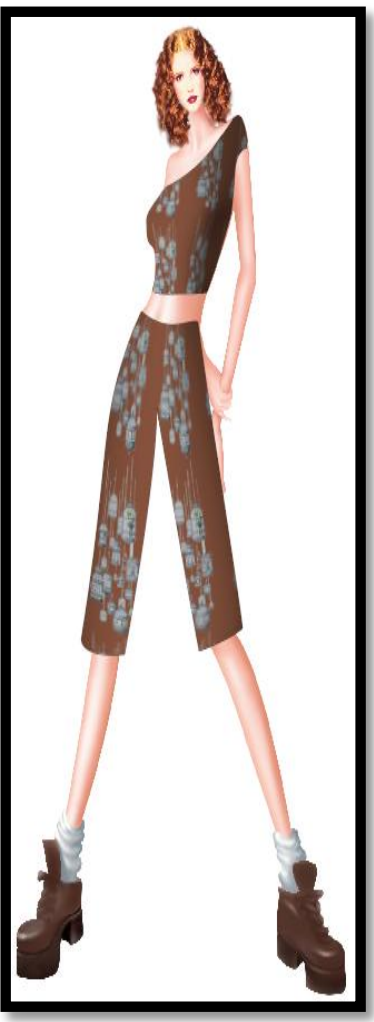

Sample 11

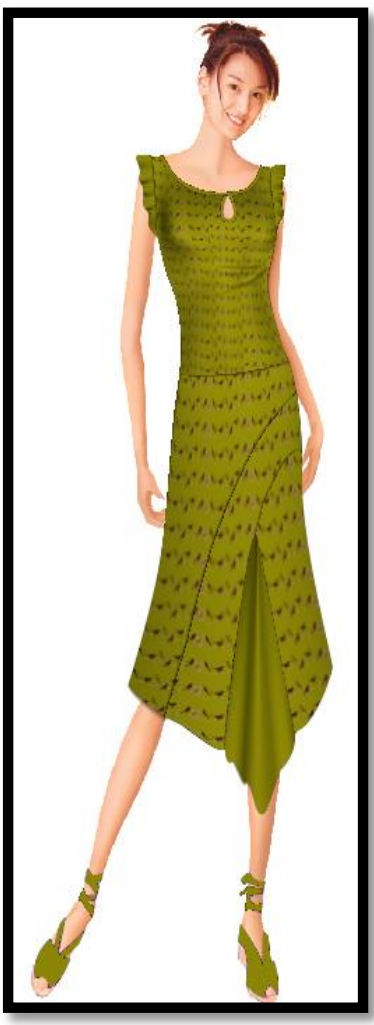

Sample 10

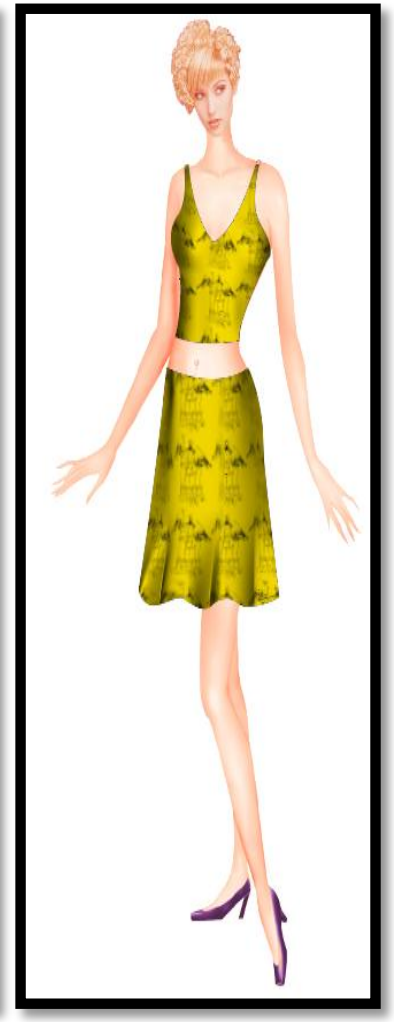

Sample 12

A survey was conducted where the prints and their application were shown to a group of 30 people between the age of 20-25 yrs. They were asked to vote for designs that they would wear and would want to see in the market. 24 out of 30 people responded well to the prints. Such positive responds to the designs shows that there could be a larger market for such prints.

\section{CONCLUSION}

To make the consumer accept truth and satisfy them with something that does not belong to this era is no joke. Consumers are the ones who will not easily get satisfied in terms of fashion. They are very strong on their tastes and preferences. Keeping this in mind, the designers maintain a thin line connecting both the eras and not overdoing either of them. This was one of the major reasons as to why consumers are willing to accept the difference created in the traditional art. The art can connect all the time periods. It also proves a point that even a 3000 thousand year old art form can still hang in a five star hotel, which shows that the art can merge with any time period. Hence, one can say that the traditional folk art forms will not have an end if it keeps having a helping hand to pull it out, whenever it starts fading. 
But the helping hand always can't be the same. It has become very monotonous for the consumers as they keep looking at these art forms on the same pace and plane.

This dissertation was started with the idea of bringing about innovation in Kalamkari Prints. On exploring the market and upon secondary research it was observed that many industry experts resonate the fact that it is not well known amongst youngsters. Thus began the project of creating prints targeted towards the youth. During the research and design process it was found that the field of contemporisation had been saturated by many designers. But in spite of that none had tried to create any design interventions in the prints. The most that had been done was changing the proportions and placements of traditional prints.

Also in spite of the all the contemporary wear created out of kalamkari, it remained heavy on the pockets and was unaffordable by the youngsters. As daily wear one could only find a stole or a kurti in the market. It was so decided that the designs would be youth centric and affordable. Designs were created taking a theme of birds. Birds were depicted against manmade objects giving it a quirky appearance. Colours were restricted to 2 or 3 rather than the traditional 5 colour designs. This gave the kalamkari a quaint look. The colours and technique used were traditional as the ultimate aim is to be able to open up markets for the craftsmen.

Through this dissertation an ancient art form was studied and adapted with newer trends, keeping the technique intact. The study stands as a documentation of how art can be adapted for various markets without necessarily intervening with traditional practices.

It acts as a resource for any future designer wanting to explore kalamkari technique and motifs and also for artists who wish to explore younger markets.

\section{REFERENCES:}

1. Sharma, E., 2015, ' Tribal Folk Arts of India', Journal of International Academic Research for Multidisciplinary, Vol 3, Issue 5, June.

2. Sharma, B., 2013, ' Study of awareness of Madhubani Painting skill among college females tudents towards self employment and economic aspects', Asian Resonance, 2, 189-193.

3. Sekar, S., 2014, 'A Study On Selected Folk Art Forms With Respect To Indian 
Fashion', International Journal Of Interdisciplinary Research And Innovations, Vol. 2, Issue 3.

4. Dallapiccola, A. L., 2011, 'Indian Painting, The Lesser Known Traditions', Niyogi Books, New Delhi.

5. Chandra. S., 2015, 'Kalamkari, The Art Of Painting With Natural Dyes', The Chitrolekha Journal On Art And Design, 2.

6. Bharatuntoldstory, 2014, (https://bharatuntoldstory.wordpress.com/tag/india/page/39).

7. (https://www.scribd.com/doc/237829316/ Paper-8-indian-Culture-and-Heritage).

8. Kotcherlakota, L. N., 2011, Intellect India, (http://trusciencetrutechnolgy.blogspot.in/ 2013/08/).

9. Wilkins, W. J., 1900, 'Hindu Mythology Vedic and Puranic', Calcutta: Thacker, Spink \& Co.; London: W. Thacker \& Co..

10. Purohit, P., 2015, 'The Study of traditional hand painted Kalamkari to Design a set of new age prints', ( http://14.139.111.26/jspui/handle/1/70), 11 May.

11. Das. S., 1992, 'Fabric Art Heritage of India', Abhinav Publications. Pg 44-56.

12. Chisti, R. \& Jain. R., 2000, 'Tradition and Beyond- Handcrafted Indian Textiles', Lustre Press, Roli books.

13. Crill, R., 2008, 'Chintz-Indian Textiles for the West', V \& A publishing in association with mapin Publishing.

14. Gillow, J.\& Barnard. N., 1991, ‘Traditional Indian Textiles', 1st ed. London: Thames and Hudson Ltd..

15. Bhatnagar, P., 2011, 'Kalamkari: Painted printed textile of India', p- 1-3.

16. Sethna, N., 1979, 'Homeage to Kalamkari', Marg Publications.

17. Rangarajan, K., 2004, Case study Tirupur, United Nations Industrial Development Organisation, p- 2-3. 
18. Hashmi, S. K., 2012, 'Market for Indian Handicraft', Excel Journal of Engineering, Technology and Management Science, Vol 1.

19. Nair, S. \& Anand, 2012, 'Kalamkari Turns Chic', (http://www.thehindu.com/life-andstyle/fashion/article3377393).

20. Sud, S. \& Sibichan, K. M., 2011, 'Tradition Fashion Interplay: An Imperative For Identity And Continuity',(Http://Process.Arts.Ac.Uk/Sites/Default/Files/Sud-Shalini-TraditionFashion- Interplay.Pdf).

21. Ghouse, S. M., 2012, 'Indian Handicraft Industry: Problems And Strategies', International Journal Of Management Research And Review , Volume 2/Issue 7/Article No-8, 11831199. 